\author{
MACIEJ PICHLAK \\ ORCID: 0000-0001-5113-9537 \\ Uniwersytet Wrocławski \\ Katedra Teorii i Filozofii Prawa
}

\title{
IDEAŁ LEGALNOŚCI W KONCEPCJI PRAWA PHILIPA SELZNICKA*
}

\begin{abstract}
Abstrakt: Artykuł ma na celu rekonstrukcję głównych założeń teorii prawa Philipa Selznicka. Jak wskazuję, centralną pozycję w tej koncepcji zajmuje pojęcie legalności, rozumianej jako moralny ideał prawa. Legalność jest tu interpretowana w sposób niepozytywistyczny, jako dążenie do ograniczania arbitralności władzy i poszerzania rozumnej deliberacji. Ideał ten, bliski tradycji republikańskiej, wyznacza zakres odpowiedzialności i rolę prawa wobec wspólnoty politycznej. Taki pogląd jest istotny także w kontekście współczesnych polskich sporów dotyczących legitymizacji i autorytetu prawa.
\end{abstract}

Słowa kluczowe: legalność, rządy prawa, prawo responsywne, ideał prawa, prawo jako instytucja

1. Philip Selznick jest znany polskiej nauce prawa przede wszystkim jako współautor, wraz z Philippe'em Nonetem, koncepcji prawa responsywnego ${ }^{1}$. Koncepcja ewolucji porządku prawnego od prawa represyjnego, przez autonomiczne, po responsywne jest dobrze znana i niezwykle wpływowa nie tylko w polskim, lecz także w światowym obiegu naukowym. Ograniczanie zainteresowania wyłącznie do niej jest jednak o tyle błędne, że jest ona jedynie wąskim — chociaż istotnym - wycinkiem dorobku amerykańskiego socjologa prawa. Co więcej, praca Noneta i Selznicka, przy całej swej oryginalności, może nieco rozczarowywać powierzchownością i skrótowością rozważań.

Nie sposób jednocześnie nie odnotować, że przywołana koncepcja wpisuje się w spójny projekt teoretyczny, jaki Selznick rozwijał w ciągu lat nie tylko w za-

* Artykuł powstał w ramach realizacji projektu badawczego „Modele prawnej regulacji ryzyka w świetle teorii refleksyjności” (nr projektu 2016/23/B/HS5/00873), finansowanego przez Narodowe Centrum Nauki.

1 P. Nonet, P. Selznick, Law and Society in Transition. Toward Responsive Law, New York 1978. Z rodzimej literatury zob. np. E. Kustra, Polityczne problemy tworzenia prawa, Toruń 1994; M. Stępień, Responsywna administracja publiczna, Toruń 2008; M. Zirk-Sadowski, Transformacja prawa podatkowego a jego wyktadnia, „Kwartalnik Prawa Podatkowego” 2004, nr 4, s. 9-20. 
kresie prawa, lecz także socjologii ogólnej. W celu pełniejszego zrozumienia jego poglądów warto więc przyjrzeć się fundamentom tego projektu, z którego wyrasta pojęcie prawa responsywnego ${ }^{2}$. Taki właśnie zamiar przyświeca niniejszemu tekstowi. Jego celem jest rekonstrukcja podstawowych założeń teoretycznych zaproponowanych przez Selznicka w odniesieniu do prawa ${ }^{3}$. Artykuł koncentruje się przy tym na zagadnieniu ideału prawa. Ideał ten autor określa jako legalność, rozumianą jednak w sposób szczególny - jako dążenie dzięki prawu do ograniczania arbitralności władzy i do poszerzania obszarów rozumnej partycypacji obywatelskiej.

Dwojakie są przesłanki takiego wyboru przedmiotu analiz. Pierwsze z nich sprowadzają się do uznania, że pojęcie ideału instytucjonalnego (master ideal) jest kluczem do zrozumienia omawianej teorii. Drugie wiążą się z kontekstem dalszych rozważań, czyli z ujawniającymi się w dzisiejszych czasach kontrowersjami — zarówno w naukach prawnych, jak i w praktyce politycznej — dotyczącymi racjonalności prawodawcy oraz legitymizacji porządku prawnego. Dość wiernie przypomina to kontekst powstania pracy Noneta i Selznicka, w której diagnozowali oni „kryzys autorytetu prawa”. Nie dziwi więc, że Selznick ma w tych kwestiach do powiedzenia coś, co pozostaje istotne także z naszej, lokalnej perspektywy ${ }^{4}$.

2. Jeśli szukać zagadnienia, która stałoby w samym centrum myśli autora, to jest nim problem wzajemnych relacji praktyk społecznych i ideałów normatywnych. Pytanie o te relacje przewija się w całym jego dorobku. Dorobku, dodajmy, bogatym i wielowątkowym, powstającym w ciągu kilkudziesięciu lat i obejmującym dziedziny socjologii organizacji, socjologii prawa oraz filozofii prawa i polityki. Dla zrozumienia stanowiska Selznicka w tej kwestii kluczowe wydają się przy tym trzy tezy. Po pierwsze, w celu właściwego odczytania sensu praktyki społecznej konieczne jest uwzględnienie ideału, na którego realizację praktyka ta jest nakierowana. Ideały wyznaczają zatem tożsamość praktyk — w tym takich jak praktyka funkcjonowania porządku prawnego. Po drugie, treści ideałów nie da się odtworzyć w oderwaniu od praktyk, w których znajdują one swoje ucieleśnienie; dopiero dzięki osadzeniu w praktyce tracą one status abstrakcyjnych pojęć i mogą być uznane za rze czywi ste zjawiska społeczne ${ }^{5}$. Po trzecie, relacja

2 Choć wspomniana książka ma dwóch autorów, istnieją dobre powody, aby wyłożone w niej tezy wiązać głównie z osobą Selznicka. W tekście będę więc konsekwentnie traktował prawo responsywne jako element szerszej teorii tego autora, unikając jałowych rozważań nad ,ilością Selznicka w Selznicku".

3 Szerzej na temat teorii Selznicka zob. M. Pichlak, Refleksyjność prawa. Od teorii społecznej do strategii regulacji i z powrotem, Łódź 2019, s. 99-135.

${ }^{4}$ Por. M. Krygier, Przez 25 lat demokraci młotkowali, że konstytucja jest ważna, zamiast pomyśleć, co zrobić, żebyśmy ja pokochali, http://wyborcza.pl/magazyn/7,124059,24939520,przez-25-lat-demokraci-mlotkowali-ze-konstytucja-jest-wazna.html (dostęp: 21.01.2020).

5 Jak pisał Selznick: „Jeśli ideały mają być traktowane z powagą, niezbędna jest rzeczywista troska o ich ucieleśnienie w działaniu, szczególnie w rutynie instytucjonalnego życia" - idem, TVA and the Grass Roots: A Study in the Sociology of Formal Organizations, Berkeley 1966, s. X. 
ideału i praktyki ma w sobie zawsze coś z dialektycznego przeciwstawienia z jednej strony konkretna interpretacja ideału może podlegać krytyce jako nazbyt oderwana od praktyki, z drugiej zaś urzeczywistnienie ideałów w praktyce zazwyczaj ma charakter ułomny i z tego punktu widzenia można krytykować praktykę.

Te trzy tezy można wiązać z trzema różnymi filozoficznymi podwalinami omawianej koncepcji, jakimi są: arystotelesowska filozofia praktyki ${ }^{6}$ (wedle której ideał ustanawia telos działania), filozofia pragmatyzmu ${ }^{7}$ (znosząca ścisłe oddzielenie faktów od wartości) oraz dialektyka ${ }^{8}$. Pytanie, czy wszystkie te nurty dają się z sobą w sposób niesprzeczny pogodzić, musi tu zostać nierozstrzygnięte. Wydaje się jednak, że pominięcie któregokolwiek z nich prowadziłoby do zniekształcenia oryginalnych poglądów Selznicka.

Odnotujmy, że prezentowane stanowisko dość wiernie oddaje typowo prawniczy sposób myślenia i może być uznane za teoretyczny wyraz tego ostatniego. Wiele podstawowych pojęć czy zasad prawnych wymaga, w celu ich właściwego zrozumienia, połączenia poziomu ideałów z poziomem praktyk instytucjonalnych. Weźmy za przykład zasadę równości wobec prawa. Z jednej strony, aby pojąć jej treść, konieczne jest zrozumienie jej etycznego sensu, czyli uzasadniającego ją ideału równości, którego zasada ta jest uszczegółowieniem. Z drugiej strony każdy prawnik doskonale zdaje sobie sprawę, że nie sposób rozprawiać o równości, nie uwzględniając sposobu, w jaki została ona urzeczywistniona i uregulowana w instytucjach prawnych, na przykład w postaci procesowych gwarancji równości stron. To właśnie praktyka procesowa, w której skutecznie przestrzega się odpowiednich przepisów procedury, sprawia, że zasada równości zyskuje realny charakter.

3. Praktykę, która urzeczywistnia istotny społecznie ideał normatywny, Selznick określa mianem instytucji. Należy więc przybliżyć to pojęcie, którego najpełniejszy opis znajdziemy w książce The Moral Commonwealth ${ }^{9}$, uchodzącej za opus magnum autora. Punktem wyjścia staje się odróżnienie pojęć instytucji oraz organizacji. Ta ostatnia ma charakter celowo-instrumentalny, będąc ukierunkowaną na realizację wyraźnie określonego zadania, definiowanego zazwyczaj za pomocą technicznego języka. W przeciwieństwie do organizacji podstawowym zadaniem instytucji nie jest realizacja celów, ale urzeczywistnianie społecznie doniosłych wartości. Nie wyklucza to również nakierowania na konkretne cele; zresztą przyjmowana

Ideały stają się wtedy „robust and grounded aspects of social reality” (,solidnymi i ugruntowanymi składowymi rzeczywistości społecznej”) — idem, Threshold Definitions, Normative Theory, and Sociology of Law, mat. konferencyjny, Tokyo 1995, s. 11.

6 Zob. M. Pichlak, op. cit., s. 112-117.

7 Zob. M. Krygier, Philip Selznick: Ideals in the World, Stanford 2012, passim; S. Taekema, The Concept of Ideals in Legal Theory, The Hague 2003, s. 100-110.

8 Zob. P. Nonet, Technique and law, [w:] Legality and Community: On the Intellectual Legacy of Philip Selznick, red. R.A. Kagan, M. Krygier, K. Winston, Lanham 2002, s. 49-66.

9 P. Selznick, The Moral Commonwealth. Social Theory and the Promise of Community, Berkeley 1992. 
przez Selznicka filozofia pragmatyzmu nie pozwala na całkowite przeciwstawianie celów i wartości. Pojęcie instytucji nie jest więc przeciwstawne pojęciu organizacji, ale przekracza to ostatnie w tym sensie, że nie może być zdefiniowane wyłącznie za pomocą technicznego języka celów (zatem nie podlega konceptualizacji wyłącznie w kategoriach racjonalności instrumentalnej). Nie da się zrozumieć instytucji — ani jako pojęcia ogólnego, ani jako konkretnego przypadku — bez odwołania do nadrzędnych ideałów i wartości, które ma ona ucieleśniać.

Zauważmy, że takie postawienie sprawy nadaje pojęciu instytucji charakter ewolucyjny — samo istnienie instytucji (bądź jej brak) nie ma w tym ujęciu charakteru absolutnego, zero-jedynkowego, ale jest raczej kwestią stopnia, zależną przede wszystkim od skali „nasycenia” danej praktyki wartościami, a co za tym idzie — od ilości i mocy powiązań tej praktyki z szerszym kontekstem życia społecznego ${ }^{10}$. Selznick rysuje ewolucyjną linię rozwoju form zrzeszenia społecznego: od organizacji, przez instytucje, po wspólnotę polityczną (polity). Pierwszy etap tego rozwoju — przejście od organizacji do instytucji - dokonuje się w procesie tak zwanej instytucjonalizacji; tym samym pojęcie to zyskuje u omawianego autora wyraźną doniosłość moralną. Instytucjonalizację postrzega Selznick przez analogię do socjalizacji jako procesu dotyczącego osób (podmiotów moralnych). Tak jak socjalizacja zakłada przyswojenie sobie przez jednostkę podstawowych dla danej społeczności przekonań moralnych, których akceptacja pozwala jej spełniać formułowane wobec niej oczekiwania społeczne - stanowi więc proces, w którym z jednostki wyłania się osoba - tak instytucjonalizacja oznacza „nasycenie” danej praktyki wartościami, które pozwolą jej pełnić odpowiednią dla niej funkcję w społeczeństwie $^{11}$. Instytucjonalizacja prawa jest więc włączeniem w porządek prawny takich wartości, które pozwolą mu spełniać jego unikalną społeczną funkcję.

Instytucja wymaga przy tym jakiejś jednoczącej zasady, uspójniającej różnorodne wartości, jakie mogą być realizowane w jej ramach. Taką właśnie rolę odgrywa wspominany już nadrzędny ideał (master ideal). Poszczególne wartości powinny być zrelatywizowane wobec tego ideału i interpretowane w jego świetle jako środki do jego urzeczywistnienia. Obecność nadrzędnego ideału nadaje instytucji ,integralność” lub „charakter” ${ }^{2}$. Oba te określenia konotują przede wszystkim pewną spójność aksjologiczną instytucji, konsekwencję w uznawaniu podstawowych wartości i zasad ${ }^{13}$. Do dokładnego znaczenia tych sformułowań, istotnych szczególnie dla zrozumienia instytucji prawa, wrócę w dalszej części.

10 Ibidem, s. 231-234

11 „W swoim najistotniejszym znaczeniu instytucjonalizacja to tyle co nasycanie wartościami ponad wymogi aktualnego zadania" — ibidem, s. 233.

12 Ibidem, s. 320-327.

$13 \mathrm{Z}$ tego powodu Selznick uznaje, że integralność (integrity) jest czymś więcej niż zwykła spójność (coherence), jest bowiem „spójnością moralna”, zapewnianą na poziomie zasad (principles) i zakładającą istnienie „moralnie zasadnych zaangażowan”” — ibidem, s. 322-323. 
4. Wspomniana dystynkcja między organizacją a instytucją świadomie nawiązuje do Weberowskiego rozróżnienia pomiędzy Zweckrationalität oraz Wertrationalität, które Selznick rozumie również jako dwie odmienne zasady integracji społecznej. Zdaniem autora tylko tam, gdzie obecna jest Wertrationalität - gdzie zatem oprócz organizacji pojawiają się instytucje — możliwe jest wykształcenie się wspólnoty politycznej (polity). To o tyle znamienna reinterpretacja Webera, że samo pojęcie instytucji w opracowaniu Selznicka odsyła do szerszej wspólnoty społecznej, w której określone ideały instytucjonalne muszą zostać zaakceptowane i rozpoznane jako rzeczywiście wiążące. Tak zatem, jak nie da się zrozumieć instytucji bez owych ideałów, tak samo nie jest możliwy jej opis w izolacji od „szczególnego miejsca, które zajmuje ona w szerszym systemie społecznym"14 i od społecznych funkcji przez nią pełnionych. Mówiąc o jakiejkolwiek instytucji, wypowiadamy się zarazem o systemie społecznym, którego pozostaje ona częścią.

Integracja społeczna oparta na oczekiwaniach moralnych rodzi społeczną odpowiedzialność poszczególnych instytucji za realizację powierzonych im wartości. Jak pisze autor, dla instytucji ,nie ma ważniejszej transakcji z otoczeniem niż negocjowanie jej miejsca w porządku moralnym, to znaczy mierzenie się z oczekiwania$\mathrm{mi}$, że będzie ona odpowiedzialna i responsywna" ${ }^{15}$. W pełni zinstytucjonalizowana (zatem „,nasycona” wartościami) praktyka społeczna jest odpowiedzialna zarówno w sensie możności pociągnięcia jej do odpowiedzialności przez społeczne otoczenie (accountable - jest to zewnętrzny, relacyjny wymiar odpowiedzialności), jak i w sensie pewnej wewnętrznej postawy, polegającej na dobrowolnym ukierunkowaniu na realizację wartości (responsible — wewnętrzny wymiar odpowiedzialności).

Jak widać, Selznick przyjmuje jakąś formę responsywności, która wypływa z samej istoty instytucji społecznej, i która charakteryzuje każdy zespół praktyk mogący być uznany za instytucję. Tak rozumiana responsywność dotyczy ontologicznego wymiaru analizy instytucji. Teoria Selznicka pozwala zatem odróżnić responsywność w sensie empirycznym, rozumianą jako jeden z możliwych modeli ukształtowania i funkcjonowania instytucji (w tym prawa), od responsywności $\mathrm{w}$ sensie ontologicznym, związanym z opisaną wyżej istotą instytucji jako realizującej społecznie istotne dążenie moralne ${ }^{16}$. Naturalnie oba wymiary responsywności oddziałują na siebie nawzajem. W szczególności responsywność ontologiczna jest bodźcem do ewolucji instytucji (z wszystkimi niejednoznacznościami i sprzecznościami tego procesu) w kierunku empirycznego modelu responsywnego. To przekonanie tworzy jedną z kluczowych idei wyrażonych we wspólnej pracy Selznicka i Noneta na temat prawa responsywnego.

14 Ibidem, s. 233.

15 Ibidem, s. 237.

16 Odpowiada to rozróżnieniu między immanentnym a kontyngentnym pojęciem refleksyjności, jakie funkcjonuje w teorii systemów. Zob. J. Winczorek, O ujęciach refleksyjności u Gunthera Teubnera i Niklasa Luhmanna i o tym, co z nich wynika dla nauki prawa, [w:] Refleksyjność w prawie. Konteksty i zastosowania, red. K. Kaleta, P. Skuczyński, Warszawa 2015, s. 177-205. 
5. Choć Selznick mówi ogólnie o wszelkich instytucjach społecznych, instytucją, która interesuje go najbardziej, jest prawo. To właśnie do prawa w pierwszym rzędzie odnoszą się przedstawione konstrukcje teoretyczne. Znamienne, że pisząc o integralności oraz charakterze instytucji - centralnym problemie w zrozumieniu całej teorii instytucjonalnej zaproponowanej przez autora - wprost odsyła on do dorobku filozofii prawa. Chodzi tu o doskonale w prawoznawstwie znane poglądy, odpowiednio, Ronalda Dworkina oraz Lona L. Fullera ${ }^{17}$. Jak wiadomo, kwestia aksjologicznej tożsamości prawa ma w teoriach obydwu tych autorów kluczowy charakter. Jednocześnie obaj uzasadniają potrzebę takiej tożsamości w sposób zbliżony do przedstawianych tu socjologicznych rozważań Selznicka - poprzez wskazanie moralnie doniosłej roli, którą prawo ma odgrywać. Dla Dworkina będzie to przede wszystkim „uzasadnianie oficjalnego użycia przymusu”"18, dla Fullera zaś „,podporządkowywanie ludzkiego zachowania kontroli zasad ogólnych"19, jednak struktura argumentacji pozostaje zbliżona, biegnąc od zdefiniowania owego wpisanego w prawo dążenia moralnego (nadrzędnego ideału) do instytucjonalnej charakterystyki prawa.

W rozumieniu nadrzędnego ideału prawa Selznick jest bliższy Fullerowi. Jego zdaniem ideał ten można określić mianem legalności (inaczej: rządów prawa), rozumianej jednak szeroko — jako dążenie do „stopniowego ograniczania zakresu arbitralności zarówno w prawie pozytywnym, jak i w jego praktycznych zastosowaniach [its administration]" 20 . Niejako pozytywną stroną tego dążenia jest poszerzanie dzięki prawu przestrzeni rozumności i wzmacnianie kanałów deliberatywnej partycypacji obywateli w życiu publicznym. Inspirację znajduje autor w klasycznej greckiej filozofii politycznej: „W swoich najbogatszych konotacjach legalność przywołuje grecką wizję porządku społecznego ufundowanego na rozumie, którego konstytutywną zasadą pozostaje sprawiedliwość"21.

6. W celu zrozumienia specyfiki pojmowania legalności, jakie proponuje Selznick, warto zestawić je z pozytywistyczną interpretacją pojęć legalności czy pra-

17 Na temat relacji między teoriami Selznicka a Dworkina, a także polemiki, do jakiej doszło między autorami na łamach „The New York Review of Books” oraz „California Law Review” zob. P. van Seters, Selznick and Dworkin. The importance of values in social and moral theory, „Issues in Legal Scholarship" 10, 2012, nr 1, s. 43-53. Jak wynika z relacji świadków (dziękuję zwłaszcza Martinowi Krygierowi za uwagi na ten temat), Selznick widział bliskie pokrewieństwo własnych poglądów z teorią Fullera. Znalazło to wyraz między innymi w życzliwych recenzjach obu najważniejszych książek Fullera. Por. P. Selznick, Book review: The Morality of Law by Lon L. Fuller, „American Sociological Review” 30, 1965, s. 947-948; idem, Book review: Anatomy of the Law by Lon L. Fuller, „Harvard Law Review” 83, 1970, s. 1474-1480.

18 „Justification for official coercion”- - R. Dworkin, Law's Empire, Cambridge MA-London 1986, s. 190. Chwilę dalej Dworkin pisze o „ogólnym uzasadnieniu dla przypadków użycia władzy przymusu przez państwo”. Polskie tłumaczenie mówi o „uzasadnieniach dla urzędowego użycia przemocy" — zob. R. Dworkin, Imperium prawa, przeł. J. Winczorek, Warszawa 2006, s. 192.

19 L.L. Fuller, Moralność prawa, przeł. S. Amsterdamski, Warszawa 1978, s. 200.

20 P. Selznick, Law, Society, and Industrial Justice, New York 1980 [wyd. oryg. 1969], s. 12.

${ }^{21}$ Ibidem, s. 18. 
worządności. Już samo określenie legalności jako „ideału”, jak czyni to autor, musi brzmieć dziwnie z perspektywy pozytywizmu. Odtwarzając to stanowisko, Andrzej Bator pisze, że legalność to tyle co „zgodność doniosłego prawnie zachowania się z odpowiednią normą (regułą) prawa pozytywnego. [...] Legalność jest pojęciem zasadniczo neutralnym aksjologicznie"22. Jako relacja zgodności legalność ma tu ściśle zdefiniowany, minimalistyczny zakres ${ }^{23}$. Nie inaczej rzecz się ma z innym bliskoznacznym pojęciem, jakim jest praworządność ${ }^{4}$. Pojęcie to może się wydawać właściwszym odpowiednikiem selznickowego ideału. Jednak rozumiana na sposób pozytywistyczny praworządność okazuje się mieć równie wąski zakres co legalność. Podstawowa różnica polega na tym, że o ile legalność odnosi się do jednostkowych działań, praworządność jest kwalifikacją organizmów zbiorowych, głównie państw. Państwo praworządne to takie, którego organy działają na podstawie i w granicach prawa. Zarówno legalność, jak i praworządność zakładają więc podporządkowanie wiążącym, ściśle zdefiniowanym standardom.

Różnica między stanowiskiem Selznicka a pozytywizmem polega więc na nadaniu pojęciu legalności odmiennego statusu. Użyteczne jest tu odwołanie do rozróżnienia między moralnością obowiązku a moralnością aspiracji ${ }^{25}$ - dla pozytywizmu zarówno legalność, jak i praworządność mieszczą się w kategorii obowiązku, funkcjonując jako podstawowe, niestopniowalne wymogi (dane działanie albo jest zgodne $\mathrm{z}$ wiążącymi normami, albo nie $)^{26}$. Mają one także charakter głównie negatywny, informując, czego nie wolno robić — działać niezgodnie z prawem. Selznick tymczasem opisuje legalność językiem aspiracji, jako dążenie, które oprócz aspektu negatywnego (ograniczanie arbitralności) ma też wyraźnie zarysowany aspekt pozytywny (poszerzanie rozumnej deliberacji i sprawiedliwości). Jako aspiracja wyznacza moralny sens „dobrego prawa”, a jej realizacja podlega stopniowaniu. Ta stopniowalna natura legalności odpowiada ogólnej logice instytucjonalizacji w ujęciu autora.

Te różnice nie oznaczają bynajmniej zanegowania pozytywistycznie pojmowanej legalności. Jest dokładnie odwrotnie — aby dążyć do realizacji ideału legalności, konieczne jest wpierw zagwarantowanie działania odpowiednich organów zgodnie z prawem. Legalność rozumiana jako obowiązek wyznacza zatem zarówno

22 A. Bator, Legalność, [hasło w:] Wielka Encyklopedia Prawa, t. 7. Teoria i filozofia prawa, red. A. Bator, J. Zajadło, M. Zirk-Sadowski, Warszawa 2016, s. 233-234.

${ }^{23}$ Zob. zwłaszcza Z. Tobor, Teoretyczne problemy legalności, Katowice 1998.

${ }^{24}$ Zob. S. Kaźmierczyk, Praworzadność, [hasło w:] Wielka Encyklopedia..., s. 346; J. Nowacki, Praworzadność. Wybrane problemy teoretyczne, Warszawa 1977; S. Wronkowska, Z. Ziembiński, Zarys teorii prawa, Poznań 2001, s. 240-252.

25 Por. L.L. Fuller, op. cit., rozdz. 1.

26 Ściśle rzecz biorąc, praworządność jest własnością stopniowalną o tyle, że działania organów państwowych mogą częściej lub rzadziej pozostawać w relacji zgodności z obowiązującym prawem. Poszczególne działania wchodzące w zakres oceny praworządności nie mają jednak charakteru stopniowalnego, odmiennie niż w ujęciu Selznicka, gdzie pojedyncze działanie może być w większym lub mniejszym stopniu arbitralne lub uwzględniać rezultaty deliberacji. 
nieprzekraczalne granice, jak i warunki realizacji legalności jako aspiracji ${ }^{27}$. Zgodnie z sugestiami samego Selznicka nie chodzi tu o zniesienie pozytywistycznych rygorów legalności, ale o ich „pogłębienie” i „,wzbogacenie" 28 . Odpowiada to poglądom autora między innymi na relacje między tak zwanym prawem autonomicznym a prawem responsywnym, a też między doktryną liberalizmu a komunitaryzmem.

Na tle pozytywizmu - i szerzej, współczesnego prawoznawstwa - propozycję Selznicka odróżnia też odejście od (typowego dla nauk prawnych) „państwo-” $\mathrm{i}$,sądocentryzmu” w postrzeganiu legalności. Jako zasada ma ona zastosowanie zarówno do praktyki sądowego, jak i administracyjnego stosowania prawa, a nawet do różnego rodzaju quasi-prawnych działań organizacji społecznych i podmiotów prywatnych ${ }^{29}$. Stąd też bierze się użyteczność omawianej teorii między innymi dla rozważań nad samoregulacją dokonywaną przez prywatne korporacje, które z perspektywy jednostki mogą mieć większe znaczenie od prawa powszechnie obowiązującego $^{30}$, a które często umykają uwadze tradycyjnie zorientowanej teorii prawa ${ }^{31}$.

Odnotujmy kolejną własność tak pojmowanej legalności. Jak już stwierdziłem, zakłada ona możliwość publicznej partycypacji (zazwyczaj w formie mechanizmów demokratycznych, choć nie jest to konieczność) w celu poszerzania obszarów rozumności w procesach podejmowania decyzji publicznych. Ponadto, jako nadrzędny ideał instytucji prawa, wyznacza ona treść i zakres odpowiedzialności tej instytucji wobec społeczeństwa. Skoro jednak tak, to legalność przestaje być pojęciem wyłącznie prawniczym. To, czego na danym etapie wymagają od nas standardy legalności, powinno być definiowane w szerokiej, publicznej debacie. Mówiąc hasłowo - prawo to zbyt poważna sprawa, aby zostawiać je w rękach samych tylko prawników.

Jest oczywiste, że tak pojęta legalność obejmuje standardy sprawiedliwości zarówno formalnej, jak i materialnej.

7. Takie pojmowanie prawa, jako instytucji, która ponosi społeczną odpowiedzialność za realizację ideału legalności, pociąga za sobą dwojakiego rodzaju konsekwencje: w sferze poglądów na prawo i polityczność (skutki „materialne”) oraz dotyczące metodologii badań nad prawem (skutki „formalne”). Spośród pierwszych niewątpliwie najbardziej doniosła jest koncepcja prawa responsywnego, czyli prawa bardziej wrażliwego społecznie, elastycznego i obywatelskiego. Jest

${ }^{27}$ Co skądinąd jest zbieżne z zapatrywaniami Fullera na relacje między obydwoma typami moralności.

${ }^{28}$ Zob. P. Selznick, The jurisprudence of communitarian liberalism, [w:] Communitarianism in Law and Society, red. P. Seters, Lanham, Md. 2006, s. 20.

${ }^{29}$ Co Selznick niezwykle ciekawie analizuje na przykładzie regulacji warunków pracy w przemyśle: idem, Law, Society...

${ }^{30}$ Zob. zwłaszcza I. Ayres, J. Braithwaite, Responsive Regulation. Transcending the Deregulation Debate, New York-Oxford 1992; C. Parker, The Open Corporation. Effective Self-Regulation and Democracy, Cambridge 2002.

31 P. Westerman, Outsourcing the Law. A Philosophical Perspective on Regulation, Cheltenham-Northampton, MA 2018, s. 9-12. 
to koncepcja dostatecznie dobrze znana, dlatego nie ma potrzeby jej tu referować. Zwróćmy jedynie uwagę, że — zgodnie z tym, co zostało podkreślone w temacie relacji między dwoma interpretacjami legalności — prawo responsywne nie oznacza bynajmniej odrzucenia standardów prawa „autonomicznego” (typowego dla spojrzenia liberalno-pozytywistycznego), ale ich wzbogacenie i przekroczenie.

W sferze filozofii politycznej przyjęte rozumienie ideału legalności lokuje autora blisko tradycji republikańskiej, z jej koncepcją wolności jako braku dominacji, czyli niepodleganiu arbitralnej władzy ${ }^{32}$. $Z$ tego też ducha pochodzi nacisk na kluczową rolę wspólnoty politycznej (polity), budowanej przez zaangażowanych obywateli. Tylko bowiem w takim środowisku ideał legalności i wizja prawa responsywnego mają szansę zaistnieć. Jest to jednak, ponownie, próba powiązania poglądów republikańskich z liberalnymi - stanowisko, które określane bywa jako republikański liberalizm ${ }^{33}$ (a co sam Selznick nazywa komunitariańskim liberalizmem ${ }^{34}$ ).

Jeśli idzie o konsekwencje metodologiczne, należy podkreślić dwie dyrektywy, charakterystyczne dla całej twórczości autora. Po pierwsze, natura relacji między ideałami a praktyką wymaga, aby analizować je zawsze w ich wzajemnych związkach. To zaś wyklucza obie postaci redukcjonizmu znane w naukach społecznych. Pierwsza z redukcji (błąd empiryzmu) programowo ogranicza się do „realnego" wymiaru funkcjonowania społeczeństwa, odrzucając wszelkie rozważania aksjologiczne jako rzekomo nienaukowe. Redukcja druga (błąd idealizmu) analizuje abstrakcyjnie ujęte zasady czy ideały, nadając im charakter samoistny i tym samym odrywając od uwarunkowań społecznych ${ }^{35}$. Wydaje się, że w prawie do pierwszego rodzaju redukcjonizmu można niekiedy zaliczyć pozytywizm prawniczy, a także empiryczną socjologię prawa; błąd idealizmu grozi z kolei między innymi teoriom prawnonaturalnym, etyce prawniczej, ale także analitycznej teorii prawa. Przeciwko obu tym redukcjonizmom Selznick wysuwa program „socjologicznego naturalizmu”, w którym naturalizm oznacza wierność wobec złożonej natury zjawisk społecznych, łączącej fakty i wartości ${ }^{36}$. Taki empiryczno-idealistyczny program badawczy ma także swoje konsekwencje praktyczne, ponieważ ucieleśnienie ogólnych wartości w praktyce społecznej konkretyzuje ich treść. Zabezpiecza to przed instrumentalizacją, której łatwo poddają się zbyt

${ }^{32}$ Zob. np. W. Ciszewski, Zasada neutralności światopoglądowej państwa, Kraków 2019, s. 6773; F. Lovett, Republicanism, [w:] The Stanford Encyclopedia of Philosophy, red. E. Zalta, https:// plato.stanford.edu/archives/sum2018/entries/republicanism/ (dostęp: 20.01.2020).

33 Zob. A. Szahaj, Jednostka czy wspólnota? Spór liberałów z komunitarystami a „sprawa polska", Warszawa 2006, s. 28 n.

${ }^{34}$ P. Selznick, The jurisprudence of communitarian...; idem, The Moral Commonwealth..., s. XI.

35 Por. J. Habermas, Faktyczność i obowiazywanie. Teoria dyskursu wobec zagadnień prawa i demokratycznego państwa prawnego, przeł. A. Romaniuk, R. Marszałek, Warszawa 2005, s. 57-81; M. Pichlak, op. cit., s. 38-41.

36 Zob. zwłaszcza P. Selznick, Sociology and natural law, „Natural Law Forum” 1961, s. 84 107; idem, Threshold Definitions... 
ogólne ideały. Autor formułuje przestrogę, zawsze aktualną, przed „intymną więzią między oportunizmem a myśleniem utopijnym", w której ramach ogólnikowe ideały służą za „ochronną przykrywkę, pod którą można podejmować decyzje w całości nastawione na własną korzyść" 37 .

Po drugie, omawiana teoria łączy podejście afirmatywne z krytycznym. Wchodząc w dyskusję z tak zwanymi teoriami krytycznymi (na przykład Critical Legal Studies), autor docenia ich wartość i użyteczność. Zastrzega jednak, że w swojej jednostronności teorie te pozostają ślepe na ideał prawa, a przez to nie są w stanie zrozumieć jego rzeczywistego sensu. W konsekwencji tracą swoją krytyczność, albowiem nie są w stanie odróżnić legitymowanego i praworządnego porządku prawnego, który wciela w życie ideał legalności, od prawa autorytarnego czy też zwykłej przemocy.

Koncepcja legalności Philipa Selznicka, tak jak cała jego teoria, z pewnością nie jest wolna od kontrowersji, na których przedstawienie nie ma tu miejsca ${ }^{38}$. Mimo możliwej krytyki jest to jedna z najciekawszych i najbardziej wartościowych teoretycznych prób uchwycenia sensu prawa.

\section{THE IDEAL OF LEGALITY IN PHILIP SELZNICK'S THEORY OF LAW}

Summary

The paper aims at reconstruction of the basic tenets of Philip Selznick's theory of law. The focal point of this theory is the concept of legality, which forms the moral ideal of law. Legality is interpreted here in a non-positivistic manner, as an aspiration to limit arbitrariness of power and to enhance reasonable deliberation. The ideal, which shows affinity with a republican tradition, determines the scope of responsibility and the role of law in a political community. Such a view is relevant, among others, in the context of the current Polish disputes about law's legitimacy and authority.

Keywords: legality, the rule of law, responsive law, the ideal of law, law as institution

\section{BIBLIOGRAFIA}

Ayres I., Braithwaite J. Responsive Regulation. Transcending the Deregulation Debate, New York-Oxford 1992.

Bator A., Legalność, [hasło w:] Wielka Encyklopedia Prawa, t. 7. Teoria i filozofia prawa, red. A. Bator, J. Zajadło, M. Zirk-Sadowski, Warszawa 2016, s. 233-234.

Ciszewski W., Zasada neutralności światopoglądowej państwa, Kraków 2019.

Dworkin R., Law's Empire, Cambridge MA-London 1986.

Dworkin R., Imperium prawa, Warszawa 2006.

37 P. Selznick, The Moral Commonwealth..., s. 249.

38 Zob. M. Pichlak, op. cit., s. 127-135. 
Fuller L.L., Moralność prawa, przeł. S. Amsterdamski, Warszawa 1978.

Habermas J., Faktyczność i obowiazywanie. Teoria dyskursu wobec zagadnień prawa i demokratycznego państwa prawnego, przeł. A. Romaniuk, R. Marszałek, Warszawa 2005.

Kaczmarek P., Tożsamość prawnika jako wykonawcy roli zawodowej, Warszawa 2014.

Kaźmierczyk S., Praworząność, [hasło w:] Wielka Encyklopedia Prawa, t. 7. Teoria i filozofia prawa, red. A. Bator, J. Zajadło, M. Zirk-Sadowski, Warszawa 2016, s. 346.

Krygier M., Philip Selznick: Ideals in the World, Stanford 2012.

Krygier M., Przez 25 lat demokraci młotkowali, że konstytucja jest ważna, zamiast pomyśleć, co zrobić, żebyśmy ja pokochali, http://wyborcza.pl/magazyn/7,124059,24939520,przez-25-lat-demokraci-mlotkowali-ze-konstytucja-jest-wazna.html (dostęp: 21.01.2020).

Kustra E., Polityczne problemy tworzenia prawa, Torun 1994.

Lovett F., Republicanism, [hasło w:] The Stanford Encyclopedia of Philosophy, red. E. Zalta, http:// plato.stanford.edu/archives/sum2018/entries/republicanism/ (dostęp: 20.01.2020).

Nonet P., Technique and law, [w:] Legality and Community: On the Intellectual Legacy of Philip Selznick, red. R.A. Kagan, M. Krygier, K. Winston, Lanham 2002, s. 49-66.

Nonet P., Selznick P., Law and Society in Transition. Toward Responsive Law, New York 1978.

Nowacki J., Praworzadność. Wybrane problemy teoretyczne, Warszawa 1977.

Parker C., The Open Corporation. Effective Self-Regulation and Democracy, Cambridge 2002.

Pichlak M., Refleksyjność prawa. Od teorii spotecznej do strategii regulacji i z powrotem, Łódź 2019.

Selznick P., Book review: Anatomy of the Law by Lon L. Fuller, „Harvard Law Review” 83, 1970, s. $1474-1480$.

Selznick P., Book review: The Morality of Law by Lon L. Fuller, „American Sociological Review” 30, 1965, s. 947-948.

Selznick P., The Jurisprudence of communitarian liberalism, [w:] Communitarianism in Law and Society, red. P. Seters, Lanham, Md. 2006, s. 19-32.

Selznick P., Law, Society, and Industrial Justice, New York 1980.

Selznick P., The Moral Commonwealth. Social Theory and the Promise of Community, Berkeley 1992.

Selznick P., Sociology and natural law, „Natural Law Forum” 1961, s. 84-107.

Selznick P., Threshold Definitions, Normative Theory, and Sociology of Law, mat. konferencyjny, Tokyo 1995.

Selznick P., TVA and the Grass Roots: A Study in the Sociology of Formal Organizations, Berkeley 1966.

Seters P. van, Selznick and Dworkin. The importance of values in social and moral theory, „Issues in Legal Scholarship" 10, 2012, nr 1, s. 43-53.

Stępień M., Responsywna administracja publiczna, Torun 2008.

Szahaj A., Jednostka czy wspólnota? Spór liberałów z komunitarystami a ,,sprawa polska”, Warszawa 2006.

Taekema S., The Concept of Ideals in Legal Theory, The Hague 2003.

Tobor Z., Teoretyczne problemy legalności, Katowice 1998.

Westerman P., Outsourcing the Law. A Philosophical Perspective on Regulation, Cheltenham-Northampton, MA 2018.

Winczorek J., O ujęciach refleksyjności u Gunthera Teubnera i Niklasa Luhmanna i o tym, co z nich wynika dla nauki prawa, [w:] Refleksyjność w prawie. Konteksty i zastosowania, red. K. Kaleta, P. Skuczyński, Warszawa 2015, s. 177-205.

Wronkowska S., Ziembiński Z., Zarys teorii prawa, Poznań 2001.

Zirk-Sadowski M., Transformacja prawa podatkowego a jego wyktadnia, „Kwartalnik Prawa Podatkowego" 2004, nr 4, s. 9-20. 